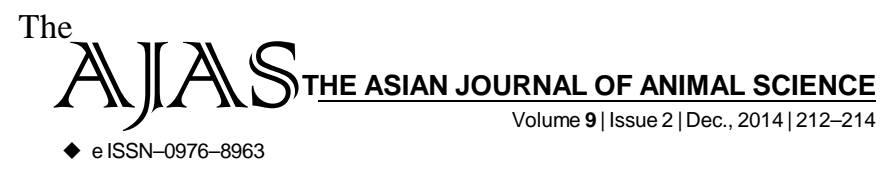

\title{
Effect of untreated and urea treated soybean straw on feeding value in lactating cows
}

\author{
R.R. SHELKE, S.D. CHAVAN AND P.A. KAHATE
}

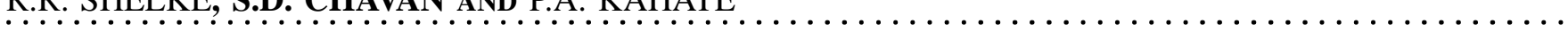

Author for Corresponding -

\section{R.R. SHELKE}

Department of Animal

Husbandry and Dairying, Dr.

Panjabrao Deshmukh Krishi

Vidyapeeth, AKOLA (M.S.) INDIA

Email: rrspkv@gmail.com

See end of the article for

Coopted authors'
ABSTRACT...... Present investigation was conducted to utilize urea treated non-conventional SBS as protein source roughage in the ration of lactating cows to find out its feeding value in respect to intake and digestibility of nutrients, milk yield and quality of milk, blood metabolic profile, feed conversion efficiency and economics. The results do suggest that 2 per cent urea treated SBS can find a place in the ration of lactating cows without any adverse effect on performance of cows. The results also points out that cow having up to $300 \mathrm{~kg}$ body weight and producing $5 \mathrm{~kg}$ milk/day can be reared and can maintain a growth rate of 0.65 per cent in milk yield per week on urea treated SBS with one kg concentrates and little support of greens.

KEY WORDS...... Conventional Jowar straw, Untreated soybean straw, 2 per cent urea treated soybean straw, DCP, TDN, DMI, Water intake, Feed conversion efficiency, Milk yield, \$ per cent FCM, Blood metabolic profile

HOW TO CITE THIS ARTICLE - Shelke, R.R., Chavan, S.D. and Kahate, P.A. (2014). Effect of untreated and urea treated soybean straw on feeding value in lactating cows. Asian J. Animal Sci., 9(2) : 212-214.

ARTICLE CHRONICLE - Received : 13.10.2014; Accepted : 30.11.2014 